\title{
Comparative Analysis of Fat and Protein Content in Milk from Alpine and Carpathian Goats
}

\author{
Alina NĂSALEĂN, Cristina STEFĂNUȚ, Emöke PALL, Rodica SOMEŞAN, Laurenţiu OGNEAN* \\ University of Agricultural Science and Veterinary Medicine, Manastur street, no. 3-5, 400037, Cluj- \\ Napoca, România , Phone: +40745267344, \\ *Corresponding author: lognean@yahoo.com \\ Bulletin UASVM Veterinary Medicine 72(2) / 2015, \\ Print ISSN 1843-5270; Electronic ISSN 1843-5378 \\ DOI:10.15835/buasvmcn-vm: 11353
}

\begin{abstract}
Goat milk shows important variations of fat and protein content, which may be due to morpho-physiological particularities of breed and specific characteristics of the geographical area. For this specie, fat and protein concentrations are fundamental indices for assessing both nutritional and biological value of milk. Such arguments were the basis of the present work, focused on the analysis of breed as a major factor of influence on the percentage of fat and protein in goat milk. Six samples of raw milk from Alpine ( $\mathrm{n}=12$ ) and Carpathian goats ( $\mathrm{n}=12$ ), representing two of the most widespread breeds in central Transylvania, were studied. The research included clinically healthy animals, selected from a herd of 60 goats of a commercial farm. The investigations involved the determination of the main physicochemical parameters of freshly milked milk samples using a semi-automatic analyzer type Ekomilk M (Milkana Kam 98-2). Data from the biochemical analysis of the two samples of milk revealed higher percentages of fat and protein for Alpine breed compared to the Carpathian breed, the differences being relevant for their individual and mean values reported for these parameters. Thus, fat percentage varied between the minimum of $5.42 \mathrm{~g} \%$ and the maximum of $7.04 \mathrm{~g} \%$ for Alpine goats milk, and between $4.27 \mathrm{~g} \%$ and $5.0 \mathrm{~g} \%$, for Carpathian goats milk. Protein percentages followed a similar trend varying between a minimum of $3.87 \mathrm{~g} \%$ and maximum of $4.27 \mathrm{~g} \%$ for Alpine goats milk and from the minimum of $4.03 \mathrm{~g} \%$ and maximum of $4.09 \mathrm{~g} \%$ for Carpathian goats milk. The overall analysis of the results obtained for the concentration of fat and protein in investigated milk samples revealed higher degree of grassland capitalization by French Alpine breed goats compared to the indigenous Carpathian breed, in central Transylvania.
\end{abstract}

Keywords: fat, goat milk, quality, protein

\section{INTRODUCTION}

As Mahe (1997) shows, milk is a complete physiological fluid secreted by the mammary gland of all mammals, to feed the newborns, but also an important food for man, being an essential constituent of diet (Park et al., 2007, Ksontini et al., 2011, Yadav et al., 2014). Goats are usually growing in hilly and mountainous areas, often around some urban regions, grouped in small or large herds (40-60 heads) and even small or specialized farms (Taftă, 2002). Herds of Carpathian goats, are less improved and still rustic, with relatively low milk production, but particularly resistant to harsh living conditions. French Alpine is an improved breed, with a well-developed body and a very good milk and offspring production. Goat milk is an essential element for numerous diets used for the prevention and treatment of diseases in humans, being a complete food with balanced protein, fat, carbohydrates, vitamins and minerals content (Michel, 2001; Park et al., 2007; Ksontini et al.,2011). One of the main aspects of goat milk composition refers to the nature of the fat in which there is the so-called medium chain triglycerides, triglycerides of fatty acids with 6 to 14 carbon atoms in their carbon chain. They usually reach a concentration of $30 \mathrm{~g} \%$, compared to cow milk of only $20 \mathrm{~g} \%$. For this reason, goat 
milk represents an interest point in the use as therapy in certain metabolic diseases (Haenlein, 2004). Goat milk proteins are more easily digested and their constituents (amino acids) are absorbed more efficiently than those in cow milk (Gills et al., 1990). Milk quality, both in terms of sanitation (Ognean, 2001), as well as nutritional value, is considered essential for the wellbeing and safety of consumers (Michel, 2001; Yadav et al., 2014). The quality of milk as an aliment, its nutritional value and preserving its optimal parameters for consumption, as well as its use as therapy adjuvant in certain metabolic diseases, were and remain major objectives for consumers.

\section{AIMS}

The aim of this research is focused on the comparative analysis of milk from two breeds of goats (Alpine French and Romanian Carpathian) from the hilly region north-west of Transylvania, in order to assess the influence of breed on fat and protein percentages in milk. The goats were selected from a herd of 60 of a private farm in Cluj County, fed in identical conditions and considered clinically healthy.

\section{MATERIALS AND METHODS}

The comparative analysis of the percentage of fat and protein of milk samples was performed during June to August 2014, using two individual raw milk samples per month, originating from the two breeds. There has been used a semi-automatic analyzer type Ekomilk M (Milkana Kam 98-2). The milk was collected aseptically from clinically healthy animals of different ages that came from the same farm, with identical feeding and living conditions. The feeding was based solely on grazing during spring, summer and autumn seasons and fibrous feed (hay, corn, cobs, roots and succulents) in winter. Milking was performed manually by the same person, strictly following milking hygiene norms. The animals were grouped in group I, consisting of goats of indigenous Carpathian breed ( $n=12$ ) and group II, consisting of French Alpine breed goats $(\mathrm{n}=12)$. The experiments consisted in determining the compositional parameters, focusing on feed utilization by both breeds, respectively, on the nutritional value and quality of milk as food in terms of the percentage of fat and protein. The statistical analysis was done using ANOVA test at a significance level $(\alpha)$ of 0.05 .

\section{RESULTS AND DISCUSSION}

After corroborating the data, the following results were obtained. For all 12 goats belonging to group II (French Alpine), the fat percentage was considerably higher than for indigenous goats, the mean values ranging between $5.42(\mathrm{~g} \%)$ and 7.04 (g\%). The lowest value recorded (5.28 g\%), was from goat number 9, value recorded at the end of August, and the highest percentage of fat was registered for goat number 2 , having a milk fat percentage up to 7.22 ( $\mathrm{g} \%$ ), recorded in early June (Tab.1).

In terms of protein percentage, the mean values were between 3.87 (g\%) and 4.27 (g\%). recorded goats number 2,7 and 10 , respectively

Tab. 1.The content of fat and protein in milk ( $\mathrm{g} \%$ ) of French Alpine goats

\begin{tabular}{|c|c|c|c|c|c|c|c|}
\hline \multicolumn{7}{|c|}{ Percentage of fat and protein in milk (g\%) } & \multirow{4}{*}{ AVERAGE $\pm S D$} \\
\hline \multirow{3}{*}{$\begin{array}{l}\text { French } \\
\text { Alpine }\end{array}$} & \multirow{3}{*}{$\begin{array}{l}\text { No.of } \\
\text { goats }\end{array}$} & \multicolumn{5}{|c|}{ samples milk } & \\
\hline & & june & \multicolumn{2}{|c|}{ july } & \multicolumn{2}{|c|}{ august } & \\
\hline & & 2 & 3 & 4 & 5 & 6 & \\
\hline \multirow{12}{*}{ Fat $(\mathrm{g} \%)$} & 1 & 6.115 .96 & 6 & 6.11 & 6.1 & 5.9 & $6.03 \pm 0.089$ \\
\hline & 2 & $7.22 \quad 7$ & 6.88 & 6.96 & 7.1 & 7.12 & $7.04 \pm 0.123$ \\
\hline & 3 & 6.216 .56 & 6.8 & 5.99 & 5.68 & 6 & $6.20 \pm 0.410$ \\
\hline & 4 & 6.626 .58 & 7 & 6.98 & 6.65 & 6.68 & $6.75 \pm 0.187$ \\
\hline & 5 & 6.296 .38 & 6.88 & 6.48 & 6.46 & 6.62 & $6.51 \pm 0.208$ \\
\hline & 6 & $6.12 \quad 6.1$ & 6.22 & 6.14 & 6.3 & 6.4 & $6.21 \pm 0.117$ \\
\hline & 7 & 7.117 .2 & 6.8 & 6.68 & 6.66 & 6.45 & $6.81 \pm 0.286$ \\
\hline & 8 & 6.256 .28 & 6.34 & 6.23 & 6.28 & 6.25 & $6.27 \pm 0.038$ \\
\hline & 9 & 5.495 .45 & 5.48 & 5.51 & 5.34 & 5.28 & $\mathbf{5 . 4 2} \pm 0.093$ \\
\hline & 10 & 5.465 .66 & 5.82 & 5.84 & 5.46 & 5.62 & $5.64 \pm 0.166$ \\
\hline & 11 & $6.1 \quad 6.2$ & 6.03 & 6.08 & 5.98 & 5.99 & $6.06 \pm 0.082$ \\
\hline & 12 & 6.326 .38 & 6.44 & 6.35 & 6.24 & 6.42 & $6.35 \pm 0.072$ \\
\hline \multirow{12}{*}{$\begin{array}{c}\text { Protein } \\
\text { (g\%) }\end{array}$} & 1 & $4.05 \quad 4.6$ & 4.08 & 4.02 & 4.12 & 4.08 & $4.15 \pm 0.218$ \\
\hline & 2 & 3.683 .99 & 3.66 & 3.88 & 4.00 & 4.01 & $3.87 \pm 0.245$ \\
\hline & 3 & 4.054 .12 & 4.1 & 4.05 & 4.02 & 3.99 & $4.05 \pm 0.048$ \\
\hline & 4 & $4.03 \quad 4.1$ & 4.1 & 4.02 & 4.2 & 4.1 & $4.09 \pm 0.064$ \\
\hline & 5 & 3.893 .98 & 4.02 & 4.06 & 4.1 & 4.08 & $4.02 \pm 0.077$ \\
\hline & 6 & $4.4 \quad 4.06$ & 4.02 & 4.09 & 4.25 & 4.1 & $4.27 \pm 0.196$ \\
\hline & 7 & 3.994 .01 & 3.88 & 4.00 & 3.66 & 3.68 & $3.87 \pm 0.318$ \\
\hline & 8 & 4.034 .09 & 4.05 & 4.06 & 4.01 & 3.99 & $4.03 \pm 0.036$ \\
\hline & 9 & 4.14 .08 & 4.07 & 4.06 & 4.02 & 4 & $4.05 \pm 0.037$ \\
\hline & 10 & 4.013 .99 & 4 & 3.88 & 3.68 & 3.66 & $3.87 \pm 0.161$ \\
\hline & 11 & 4.13 .99 & 3.95 & 3.66 & 4 & 4.01 & $3.95 \pm 0.151$ \\
\hline & 12 & 3.683 .89 & 4.04 & 4.03 & 4.01 & 4.06 & $3.96 \pm 0.157$ \\
\hline
\end{tabular}


maximum average was 4.27 ( $\mathrm{g} \%$ ). The maximum individual value was $4.4(\mathrm{~g} \%)$, recorded for goat 6 in early June and the minimum one was $3.66(\mathrm{~g} \%)$, for goat number 10 at the end of August. These results indicate that during examined period there were major variations of fat and protein percentage, values raging from high to low and vice versa (Tab.1).

The statistical analysis of the values presented in table one pointed out that there are no statistically significant differences between the fat ant protein concentrations depending of the moment of sampling $(\mathrm{p}=0.12$, respectively $\mathrm{p}=0.53$ ), but the variation between animals is

Tab.2.The content of fat and protein in milk (g\%) of Carpathian goats

\begin{tabular}{|c|c|c|c|c|c|c|c|}
\hline \multicolumn{7}{|c|}{ Percentage fat and protein in milk (g\%) } & \multirow{4}{*}{ AVERAGE $\pm S D$} \\
\hline \multirow{3}{*}{ Carpathian } & \multirow{3}{*}{$\begin{array}{l}\text { No.of } \\
\text { goats }\end{array}$} & \multicolumn{5}{|c|}{ samples milk } & \\
\hline & & june & \multicolumn{2}{|c|}{ july } & \multicolumn{2}{|c|}{ august } & \\
\hline & & 2 & 3 & 4 & 5 & 6 & \\
\hline \multirow{12}{*}{ Fat (g\%) } & 1 & $4.8 \quad 4.6$ & 4.66 & 4.85 & 4.66 & 4.68 & $4.70 \pm 0.095$ \\
\hline & 2 & 4.64 .55 & 4.6 & 4.8 & 4.91 & 4.88 & $4.72 \pm 0.158$ \\
\hline & 3 & 4.664 .8 & 4.76 & 4.81 & 4.82 & 4.77 & $4.77 \pm 0.058$ \\
\hline & 4 & $4.2 \quad 4.22$ & 4.3 & 4.2 & 4.1 & 4.2 & $4.20 \pm 0.063$ \\
\hline & 5 & 4.34 .35 & 4.12 & 4.14 & 4.22 & 4.5 & $4.27 \pm 0.142$ \\
\hline & 6 & 4.254 .32 & 4.3 & 4.5 & 4.8 & 4.82 & $4.49 \pm 0.255$ \\
\hline & 7 & 4.254 .80 & 4.11 & 4.2 & 4.06 & 4.12 & $4.25 \pm 0.274$ \\
\hline & 8 & 5.014 .98 & 4.89 & 5.02 & 4.92 & 4.84 & $4.94 \pm 0.071$ \\
\hline & 9 & 4.894 .86 & 4.80 & 4.98 & 5.01 & 5.02 & $4.92 \pm 0.089$ \\
\hline & 10 & 4.924 .94 & 4.66 & 4.55 & 4.66 & 4.80 & $4.75 \pm 0.157$ \\
\hline & 11 & 4.864 .92 & 4.89 & 4.62 & 4.80 & 4.66 & $4.79 \pm 0.124$ \\
\hline & 12 & 4.985 .01 & 5.02 & 4.96 & 5.01 & 5.06 & $\mathbf{5} \pm 0.034$ \\
\hline \multirow{12}{*}{$\begin{array}{c}\text { Protein } \\
(\mathrm{g} \%)\end{array}$} & 1 & 4.044 .08 & 4.10 & 4.02 & 4.06 & 4.12 & $4.07 \pm 0.037$ \\
\hline & 2 & 4.064 .08 & 4.06 & 4.06 & 4.08 & 4.02 & $4.06 \pm 0.021$ \\
\hline & 3 & 4.054 .06 & 4.08 & 4.06 & 4.07 & 4.06 & $4.06 \pm 0.010$ \\
\hline & 4 & 4.084 .10 & 4.09 & 4.09 & 4.12 & 4.11 & $4.09 \pm 0.014$ \\
\hline & 5 & 4.044 .03 & 4.03 & 4.06 & 4.06 & 4.03 & $4.04 \pm 0.014$ \\
\hline & 6 & 4.044 .06 & 4.04 & 4.10 & 4.02 & 4.06 & $4.05 \pm 0.027$ \\
\hline & 7 & 4.034 .02 & 4.02 & 4.06 & 4.01 & 4.08 & $\mathbf{4 . 0 3} \pm 0.027$ \\
\hline & 8 & 4.094 .11 & 4.10 & 4.09 & 4.06 & 4.10 & $4.09 \pm 0.017$ \\
\hline & 9 & 4.084 .05 & 4.06 & 4.08 & 4.06 & 4.08 & $4.06 \pm 0.013$ \\
\hline & 10 & 4.094 .09 & 4.02 & 4.02 & 4.08 & 4.09 & $4.06 \pm 0.035$ \\
\hline & 11 & 4.084 .06 & 4.08 & 4.06 & 4.10 & 4.10 & $4.08 \pm 0.017$ \\
\hline & 12 & 4.044 .06 & 4.07 & 4.05 & 4.06 & 4.02 & $4.05 \pm 0.017$ \\
\hline
\end{tabular}

very statistically significant $(\mathrm{p}<0.001$, respectively $\mathrm{p}<0.001$

In the case of indigenous goats grouped in group I, the values recorded were much lower for both fat and protein, comparatively to group II, represented by Alpine goats. The documented mean values were between $4.27(\mathrm{~g} \%)$ and 5.00 ( $\mathrm{g} \%$ ) for fat percentage. The lowest individual value was recorded in goat 7 in early August and was 4.06 (g\%), while the maximum percentage was $5.06(\mathrm{~g} \%)$ for goat 12 at the end August (Tab.2).

The mean protein percentage ranged from $4.03(\mathrm{~g} \%)$ to 4.09 (g\%).The percentage of protein register a maximum individual value of 4.12 ( $\mathrm{g} \%$ ) for goat 4 in early August and a minimum individual value of 4.01 (g\%) for goat seven, recorded in early August (tab.2). The milk concentration of fat and protein did not vary significantly between the six sampling periods $(\mathrm{p}=0.51$, respectively $\mathrm{p}=0.83)$ for the Carpathian breed goats, but there were statistically significant differences between the animals $(\mathrm{p}<0.001$, respectively $\mathrm{p}<0.001)$.

The variances observed between the two breeds were analyzed statistically. The results of ANOVA test pointed out that the differences recorded for fat content were very significant from the statistical point of view $(p<0.001)$, while the variations of protein percentages were distinctly significant $(p=0.009)$. These results confirm the different capitalization of feed by the two breeds investigated, in identical living and feeding conditions.

\section{CONCLUSION}

The overall analysis of the data collected in this research points out that milk of French Alpine goats (group II) had higher values of fat and protein compared to the one of Carpathian goats (group I). The conclusion of the present study emphasizes the better capitalization of feed by imported French Alpine goats, as well as the higher quality of their milk, compared to indigenous Carpathian breed goats. The French Alpine breed can easily be reared by farmers, having a bigger milk production and of notably higher quality regarding the content of fat and protein. More studies are needed on this subject in order to assess the real potential of goat milk as adjuvant in treating certain metabolic diseases, as 
well as evaluating its true nutritional value and the optimal parameters for its consumption.

\section{REFERENCES}

1. Gills R, Howard W, Leslie K, Lissemore K (1990). Economics of mastitis control. J Dairy Sci 73:3340-3348.

2. Haenlein GF (2004). Goat milk in human nutrition. Small Rumin Res 51:155-163.

3. Ksontini H, Faten K, Moktar H (2011). Microflora distribution and assessment of microbiological quality milk from Tunisian collection centres. African Journal of Microbiology Research 5(12):1484-1491.

4. Mahe S (1997). Valeur nutritionnelle du lait en alimentation humaine Interets nutritiounel et dietetique du lait chevre. Les Colloques INRA 81:9-24.

5. Michel V (2001). Microbial flora of raw cow's milk and influence of the conditions of production. Academic Journals, 575-591.
6. Ognean L (2001). Configuraţia lactocitogramei la capră şi corelarea ei cu starea de sănătate a glandei mamare. Lucrări ştiinţifice Univ de Stiinţe Agricole şi Medicină Veterinară "Ion Ionescu de la Brad" Iaşi, 44 (3), seria Medicină Veterinară:258-264.

7. Park Y (2006). Goat milk. Chemistry and Nutrition; Handbook of milk of nonbovine mammals. Blackwell Publishing, Oxford, 34-58.

8. Park YW, Ju'Arez M, Ramos M, Haenlein Gfw (2007). Physico-chemical characteristics of goat and sheep milk. Small Rumin Res 68:88-113.

9. Taftă V (2002). Productia si reproductia caprinelor. Ceres, Bucuresti.

10. Yadav Jyoti, Saurav Paul, Jyotsna Kiran Peter, Yashab Kumar, Ajay Kumar, Singh, Florin Masih, Harison Masih (2014). Comparative evaluation of pathogenic bacterial incidence in raw and pasteurized milk. International Journal of Engineering Science Invention 3(5):11-20. 